\title{
INORGANIC CRYSTALLOGRAPHY AND GEOSCIENCES
}

${ }^{a}$ Dipartimento Geomineralogico, Bari, Italy. ${ }^{b}$ Dipartimento di Scienze della Terra, Ferrara, Italy. E-mail: mesto@geomin.uniba.it

The Ti-rich biotite from graphite-bearing metapelitic xenoliths (El Joyazo - Spain) have been recently studied trough a multitechnical approach [1]. The study, combining several techniques, showed $\mathrm{TiO}_{2}$ content ranging from 4.5 to $4.9 \mathrm{wt} \%$ and a constant $\mathrm{X}_{\mathrm{Fe}}=0.67$. According to the results of their investigations, Cesare et al. [1], suggest that titanium (as $\mathrm{Ti}^{4+}$ ) is logged only in octahedral site. The aim of the present work is the investigation both the oxidation state and the site partition of titanium accepting the main crystal chemical conclusion achieved by [1]. The following Ti-coordination polyhedra have been considered during XPS analysis: 4-fold coordination (tetrahedral), 5+1 coordination (distorted octahedral), 6-fold coordination (regular octahedral). In order to obtain the best fitting, the $\mathrm{BE}$ of the $\mathrm{Ti}^{4+}$ for the octahedral and tetrahedral coordination have been determined following the procedure in [2]. While the $\mathrm{BE}$ for $\mathrm{Ti}^{4+}$ in distorted octahedron $(5+1)$ has been obtained by means of ab initio calculations [3]. The result of XPS investigation shows that $\mathrm{Ti}^{4+}$ populates both tetrahedral and octahedral sites. Taking in account the structural formula proposed by [1], we note that the entrance of $\mathrm{Ti}^{4+}$ in the tetrahedral site and of $\mathrm{Al}^{3+}$ in octahedral site, in the same amount, results in a both better balance of the substitution mechanisms and in a better m. a. n.'s agreement between EPMA and SCXRD data.

[1] Cesare B., Cruciali G., Russo U., Am. Mineral., 2003, 88, 583-595. [2] Malitesta C., Losito I., Scordari F., Schingaro E., Eur. J. Mineral., 1995, 7 , 847-858. [3] Saunders V.R. et al., CRYSTAL'03 User Manual, Turin, University of Torino, 1999.

Keywords: Ti-bearing micas, XPS analysis, Ti speciation

\section{P.10.05.15}

Acta Cryst. (2005). A61, C379

Mg, Al, Si, Ca -Bearing Magnetite from Korshunovskoe, East Siberia

Barbara Lavina ${ }^{\mathrm{a}}$, Alexander Polozov, ${ }^{\mathrm{b}}$ Robert T. Downs ${ }^{a}$ Dipartimento di Mineralogia e Petrologia, University of Padova, Italy. ${ }^{\mathrm{b}}$ Institute of Geochemistry Siberian Branch of Russian Academy of Sciences, Irkutsk, Russia. ${ }^{\mathrm{c} D e p a r t m e n t ~ o f ~ G e o s c i e n c e s, ~ U n i v e r s i t y ~}$ of Arizona, Tucson, Arizona. E-mail: barbara.lavina@unipd.it

The crystal chemistry of magnetite crystals from Korshunovskoe iron ore deposit were investigated by means of single-crystal X-ray diffraction and electron microprobe analyses. The crystals were picked from two rock samples and show significant $\mathrm{Mg}, \mathrm{Al}, \mathrm{Si}$ and $\mathrm{Ca}$ content The cell parameters are close to $8.392 \AA$, slightly smaller than for pure magnetite, and the oxygen positional parameters are close to 0.2550 . After refinement, weak residual peaks were systematically founded in position 48f; possibly an indication of interstitial atoms [1]. Introducing an atom in the suggested position led to significant improvement in the refinement disagreement factors [2]. Refined site occupancies led to an estimate of about 25 electrons both in the $\mathrm{T}$ and $\mathrm{M}$ sites, consistent with the substitution in both sites of some elements lighter than iron. However the number of electrons calculated from the microprobe analyses is significantly lower, therefore some of the detected cations could not be part of the magnetite structure, however no other phases were detected from the powder diffraction profile.

[1] Fleet M.E., Acta Cryst., 1982, B38, 1718. [2] Hamilton W.C., Acta Cryst., $1965,18,502$.

Keywords: magnetite, structure analysis, interstitial atoms

\section{P.10.05.16}

Acta Cryst. (2005). A61, C379

Analysis of Structure Factors of 2D-connected Crystal Structures Jordi Rius, Inmaculada Peral, Carles Miravitlles, Departament de Cristallografia i Química de l'Estat Solid, Institut de Ciència de Materials de Barcelona-CSIC, Catalunya, Spain. E-mail: jordi.rius@icmab.es

The solution of complex inorganic structures from powder diffraction data is much easier when dominant scatterers are present
Due to the small X-ray scattering contrast between Si and O, solution of complex zeolitic materials is still difficult. One characteristic of the latter is their 3D connectivity and the known tetrahedral coordination that means that once the positions of the $\mathrm{Si}$ are located, the positions of the $\mathrm{O}$ atoms can be interpolated. In other words, the positions of the $\mathrm{O}$ atoms are not independent from the Si positions. The ideal situation for solving crystal structures from powder data at moderate resolution $(\mathrm{d}>2 \AA)$ by direct methods would be to have at one's disposal structure factor moduli with the contributions of the $\mathrm{O}$ atoms removed [1], [2].

In order to better analyse this possibility, the modulus $\mathrm{C}$ and the phase angle $\delta$ of group structure factor of one triangular $\mathrm{O}$ polyhedron around a central $\mathrm{Si}$ atom have been plotted as a function of its orientation. The respective variation coefficients of $\mathrm{C}$ are 9.1 and $21.5 \%$ at 2 and at $1.85 \AA$ resolution, respectively, while the corresponding standard deviations of $\delta$ are $27^{\circ}$ and $12^{\circ}$. These values are used to estimate the accuracy of the structure factors of an hypothetical planar 2D connected model built of such triangular polyhedra after removal of the average $\mathrm{O}$ contribution.

[1] Rius J., Acta Cryst., 1993, A49, 406. [2] Rius J., Z. Kristallogr., 2004, 219 , 826.

Keywords: powder structure solution, complex compounds crystal structure, inorganic materials

\section{P.10.05.17}

Acta Cryst. (2005). A61, C379

The Spinels Unit Cell Parameter as Diamond Potentiality Indicator

Reyhaniyyih I. Kassimova, Moscow State University n.a.M.V. Lomonosov (The Lomonosov Moscow State University) Geological Faculty, Chair of mineralogy, crystallography \& crystallochemistry, Institute of Mineralogy. E-mail: fizza@mail.ru

The Russia (Yakut and Archangel kimberlite provinces), South Africa,North America and Australia spinels grains (about 500) content from different types deep rocks was discovered. The spinels are characterised by two types of substitutions:1) $\left.\mathrm{Cr}^{(3+)}-\mathrm{Al}^{(3+)}, 2\right) \mathrm{Cr}^{(3+)}$ $\mathrm{Fe}^{(3+)}+\mathrm{Ti}^{(4+)}$

The clear lineal dependance between unit cell parameter $\left(\mathbf{a}_{\mathbf{0}}\right)$ and oxides contents was not observed. The obtained data are testified the limitations of using the diagram based on the Yakut and Archangel regions spinels $\mathrm{X}$-ray data.The lineal dependance can be observed within the samples with $\mathrm{Cr}^{(3+)}-\mathrm{Al}^{(3+)}$ or $\mathrm{Cr}^{(3+)}-\mathrm{Fe}^{(3+)}$ isomorphism. The realisation both substitutions schemes and also enough amount of titanium (more than 2 mas.\%) in spinel structure and the wide substitutions between $\mathrm{Mg}^{(2+)}-\mathrm{Fe}^{(2+)}$ disturb the lineal dependance between oxide contents and $\mathbf{a}_{\mathbf{0}}$ : decreasing $\mathbf{a}_{0}$ is held by decreasing $\mathrm{Al}_{2} \mathrm{O}_{3}$, and increasing $\mathbf{a}_{0}$ depends not only from chrome (III) oxide, but from $\mathrm{Cr}_{2} \mathrm{O}_{3}, \mathrm{Fe}_{2} \mathrm{O}_{3}$ and $\mathrm{TiO}_{2}, \mathrm{MgO}$ and $\mathrm{FeO}$ togerther influence. Therefore during first steps searching spinels upon X-ray data one can get highferrous and titanious varietes.

The two lines have been identified between $\mathbf{a}_{0}$ and IR-spectra absorbence maximum within spinels from kimberlites which indicates on a crystallyzation consequence and a fluid-magmatic differentiation on the first mantle magmas.

This approach also can be used as a guide by Geological Enterprises to search spinels as mineral-indicators on diamondferrous rocks.

Keywords: spinels, unit cell parameter, IR-spectra absorbence maximum

\section{P.10.05.18}

Acta Cryst. (2005). A61, C379-C380

Variations in the Morphologies and Magnetic Properties of Magnetite Crystals in Bacteria

Mihály Pósfai $^{\mathrm{a}}$, Ilona Kósa ${ }^{\mathrm{a}}$, Edward T. Simpson ${ }^{\mathrm{b}}$, Ryan K.K. Chong ${ }^{\mathrm{b}}$, Takeshi Kasama $^{\mathrm{c}, \mathrm{b}}$, Zoltán Kristóf ${ }^{\mathrm{d}}$, Rafal E. Dunin-Borkowski ${ }^{\mathrm{b}, \mathrm{c}}$, ${ }^{a}$ Dept. of Earth and Environmental Sciences, University of Veszprém, Hungary. ${ }^{\mathrm{b}}$ Dept. of Materials Science and Metallurgy, University of Cambridge, UK. ${ }^{\mathrm{c}}$ The Institute of Physical and Chemical Research, 


\section{INORGANIC CRYSTALLOGRAPHY AND GEOSCIENCES}

Hatoyama, Japan. 'Dept. of Plant Anatomy, Eötvös University, Budapest, Hungary. E-mail: posfaim@almos.vein.hu

We have used a combination of advanced transmission electron microscopy techniques to study the physical and chemical properties of intracellular ferrimagnetic magnetite $\left(\mathrm{Fe}_{3} \mathrm{O}_{4}\right)$ crystals inside magnetotactic bacteria collected from lakes and streams.

The orientations and morphologies of the crystals in a double magnetosome chain were identified using electron diffraction, high-resolution electron microscopy and high-angle annular dark field electron tomography. The chain is analogous to beads on a string, in which biological control appears to be stricter in setting the [111] magnetocrystalline easy axis of the crystals to be parallel to the chain axis than in constraining their orientation about this direction. We have used off-axis electron holography to record magnetic induction maps from the same particles. The magnetic signal is dominated by inter-particle interactions and by the shapes of the individual crystals.

We have also studied the diversity of magnetosomes in bacteria collected from Lake Balaton. In stained thin sections of cocci, magnetite crystals appear to be anchored to the inner cell membrane. They are enveloped by stained material, apparently representing the magnetosome membrane. The cells do not contain detectable iron outside the magnetite magnetosomes.

Keywords: biomineral, magnetism, advanced electron microscopy

\section{P.10.05.19}

Acta Cryst. (2005). A61, C380

\section{Going Inside Fettelite, a Ho-Sulfosalt Mineral}

Mónica Pérez-Priede ${ }^{\mathrm{a}}$, Xavier Xolans Huguet ${ }^{\mathrm{b}}$, Dámaso Moreiras Blanco $^{\mathrm{c}}$, Santiago García Granda ${ }^{\mathrm{a}}$, ${ }^{\mathrm{a}}$ Department of Physical and Analytical Chemistry, University of Oviedo, Spain. ${ }^{\mathrm{b}}$ Department of Crystallography, Mineralogy and Mineral Deposits, University of Barcelona, Spain. ' Department of Geology, University of Oviedo, Spain. E-mail: mpp@fq.uniovi.es

Fettelita's name honours Mr. M Fettel who found it. The empirical formula from microprobe analysis (based on $24 \mathrm{Ag}$ atoms) is $\mathrm{Ag}_{24} \mathrm{Hg}$ $\mathrm{Cu}_{0.04} \mathrm{Fe}_{0.03} \mathrm{Tl}_{0.02} \mathrm{~Pb}_{0.01} \mathrm{Sb}_{0.07} \mathrm{As}_{5.01} \mathrm{~S}_{20.07}$, ideally $\mathrm{Ag}_{24} \mathrm{HgAs}_{5} \mathrm{~S}_{20}$, and the crystal system trigonal [1].

Despite Fettelite sensitivity to X-Ray exposition, we have tried to elucidate its structure. As in Laffittite [2], metal and sulphur atoms form hexagonal rings linked by sharing their edges giving rise to parallel sheets when view along the $\mathrm{c}$ axis (see figure). The sheets join themselves composing a three dimensional network. Coordination around the metal ion is typical for sulfosalt structures.

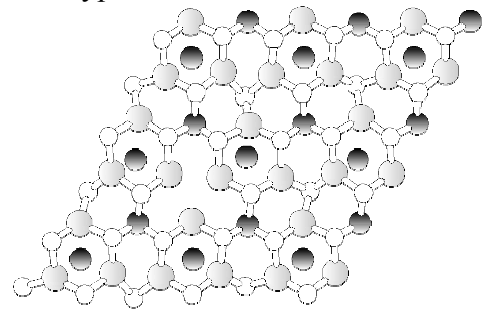

[1] Wang N., Paniagua A., N. Jb. Miner. Mh., 1996, H. 7, 313-320. [2] Nakai I., Appleman D. E., American Mineralogist, 1983, 68, 235-244.

Keywords: sulfosalts, mineral crystal structures, mineralogy and crystallography using $\mathrm{X}$-ray diffraction

\section{P.10.05.20}

Acta Cryst. (2005). A61, C380

Crystal Structure of Non-Metamict Minerals of Chevkinite Group Federica Liziero $^{\mathrm{a}}$, Elena Belluso ${ }^{\mathrm{b}}$, Susanna Carbonin ${ }^{\mathrm{a}}$, Luca Nodari ${ }^{\mathrm{c}}$, Umberto Russo ${ }^{c},{ }^{a}$ Dip. Mineralogia e Petrologia, Univ. Padova. ${ }^{b}$ Dip. Sc. Mineralogiche e Petrologiche, Univ. Torino. ${ }^{c}$ Dip. Scienze Chimiche,Univ.Padova. E-mail: federica.liziero@unipd.it

Crystal chemistry and structure of chevkinites occurring in a hightemperature pneumatolitic vein from Tangir Valley (Pakistan) and in some silica-saturated/oversaturated syenite clasts from São Miguel Island (Azores) were investigated.

Electron microprobe analyses suite the formula $\mathrm{A}_{4} \mathrm{BC}_{4} \mathrm{O}_{8}\left(\mathrm{Si}_{2} \mathrm{O}_{7}\right)_{2}$, where $\mathrm{A}=\mathrm{REE}, \mathrm{Ca}, \mathrm{Th} ; \mathrm{B}=\mathrm{Fe}, \mathrm{Mn}, \mathrm{Mg} ; \mathrm{C}=\mathrm{Ti}, \mathrm{Fe}, \mathrm{Nb}$. Ce and $\mathrm{La}$ are the predominant elements in A sites: $\mathrm{Ce}_{2} \mathrm{O}_{3}$ range from $22 \%$ to $24 \%$ (wt.) and $\mathrm{La}_{2} \mathrm{O}_{3}$ from $10 \%$ to $14 \%$. The major components in octahedral sites (B and $\mathrm{C}$ ) are $\mathrm{Fe}$ and $\mathrm{Ti}$ : $\mathrm{FeO}$ range from $11 \%$ to $12 \%$ (wt.) and $\mathrm{TiO}_{2}$ from $15 \%$ to $17 \%$. The crystal structure was refined in the space group $C 2 / m$ to conventional $\mathrm{R}(\mathrm{I} / \sigma(\mathrm{I})>4)$ of $\cong 2 \%$. Site occupancies were calculated on the basis of electron microprobe results, refinement electrons and bond valence analysis. $\mathrm{An} \mathrm{Fe}^{3+} / \Sigma \mathrm{Fe}$ ratio of 0.58 for Pakistan chevkinite was determined from Mössbauer spectroscopy. A preliminary spectral analysis points to the presence of two different types of $\mathrm{Fe}^{2+}$, both in octahedral sites. TEM investigations revealed the high crystallinity of both chevkinites. At the SAED scale the Pakistan chevkinite shows absence of structural defects, whereas the Azores one shows strekked spots along [001] and [-111] directions. HRTEM study is in progress in order to explain the presence of defects in some directions and to evidence structural regularity in others.

Keywords: silicates of rare elements, crystal chemistry and structure, TEM

\section{P.10.06.1}

Acta Cryst. (2005). A61, C380

Structure of New Rare-Earth Borates $\operatorname{Ln}\left[\mathrm{B}_{6} \mathrm{O}_{9}(\mathrm{OH})_{3}\right]$ and its Relation to Boracites

Anna Ivanova, Elena Belokoneva, Olga Dimitrova, Sergej Stefanovich, Moscow State University, Moscow, Russia. E-mail: an_ivanova@mail.ru

The crystal structures of rare-earth borates $\mathrm{Ln}\left[\mathrm{B}_{6} \mathrm{O}_{9}(\mathrm{OH})_{3}\right]$, $\mathrm{Ln}=\mathrm{Sm}-\mathrm{Lu}$, synthesized under hydrothermal conditions, are solved in the space group $R 3 c$ ( $\mathrm{Ln}=\mathrm{Ho}, a$ 8.385(9), $c$ 20,71(4), $R=29 \%$, and $\mathrm{Ln}=\mathrm{Gd}, a$ 8.410(4), $c$ 20,72(1), $R=4.8 \%)$. New borates belong to hexaborate group. The polar anionic framework consists of fundamental building blocks FBB $[3 \mathrm{~T}+3 \Delta]$ : six-membered rings of regularly alternating $\left(\mathrm{BO}_{4}\right)$-tetrahedra and $\left(\mathrm{BO}_{3}\right)$-triangles. Atoms of $\mathrm{Ln}$ and $\mathrm{H}$ are located in wide channels along threefold axis. Lnborates have the closest structural relation to synthetic boracite $\mathrm{Li}_{4} \mathrm{~B}_{7} \mathrm{O}_{12} \mathrm{Cl}$ with the same FBB [1].

Structural relationship between all boracite modifications can be revealed, if to pay attention to clusters of four hexaborate blocks of two types [6T] or $[3 \mathrm{~T}+3 \Delta]$. In the cubic boracites $\mathrm{M}_{3} \mathrm{~B}_{7} \mathrm{O}_{13} \mathrm{Cl}(\mathrm{M}=$ $\mathrm{Mg}, \mathrm{Fe})[2]$ and many synthetic analogues four blocks [6T] are linked via vertices. The trigonal and orthorhombic distortion [3] is caused by increase one of $\mathrm{B}-\mathrm{O}$ bond and corresponding decrease of $\mathrm{B}$ coordination from tetrahedron to triangle. In the cubic $\mathrm{Li}_{4} \mathrm{~B}_{7} \mathrm{O}_{12} \mathrm{Cl}$ such clusters consist of four blocks $[3 \mathrm{~T}+3 \Delta]$. In the trigonal $\mathrm{Ln}\left[\mathrm{B}_{6} \mathrm{O}_{9}(\mathrm{OH})_{3}\right]$, in comparison with $\mathrm{Li}_{4} \mathrm{~B}_{7} \mathrm{O}_{12} \mathrm{Cl}$, there is one $\mathrm{B}$-atom less, what leads to destruction of such clusters with keeping single six-membered rings.

[1] Jeitschko W., Bither T.A., Bierstedt P.E., Acta Cryst., 1977, B33, 2767. [2] Sueno S., Clark J.R., Papike J.J., Konnert J.A., Am. Mineral., 1973, 58, 691. [3] Dowty E., Clark J.R., Z. Kristallogr., 1973, 138, 64.

Keywords: rare-earth borates, boracites, structural topology

\section{P.10.06.2}

Acta Cryst. (2005). A61, C380-C381

Zeolites Gismondine and Li-ABW under Pressure: Synchrotron XRPD and MD Simulations

Maria Cristina Betti ${ }^{\mathrm{a}}$, Ettore Fois ${ }^{\mathrm{b}}$, Aldo Gamba ${ }^{\mathrm{b}}$, Cinzia Medici ${ }^{\mathrm{b}}$, Simona Quartieric , Gloria Tabacchi ${ }^{\mathrm{b}}$, Giovanna Vezzalini ${ }^{\mathrm{a}}$, Stefano Zanardi ${ }^{\mathrm{a}},{ }^{a}$ Department of Earth Sciences, University of Modena and Reggio Emilia, Italy. ${ }^{b}$ DSCA, University of Insubria, Como, Italy. ${ }^{c}$ Department of Earth Sciences, University of Messina. E-mail: bmc@unimo.it

The response to compression of the zeolites gismondine and of LiABW were explored by synchrotron X-ray powder diffraction and ab-initio Molecular Dynamics simulations. Different pressuretransmitting media were used: silicon oil and propane-isopropane as non-penetrating media, and a water-methanol mixture as penetrating one. The applied pressure spans from room pressure to about $10 \mathrm{GPa}$. The data collection was performed at SNBL1 beamline at ESRF (Grenoble) using a wavelength of $0.7 \AA$ and a MAR 345 (pixel size 